\title{
Income Impacts of Credit on Accessed Households in Rural Vietnam: Do Various Credit Sources Perform Differently?
}

\author{
D. X. Luan ${ }^{1,2}$, S. Bauer ${ }^{1}$, R. Kühl ${ }^{1}$ \\ ${ }^{1}$ Justus-Liebig University Giessen, Inst. of Farm and Agribusiness Management - Project and Regional \\ Planning, Germany \\ ${ }^{2}$ Faculty of Economics and Rural Development, Thai Nguyen University of Agriculture and Forestry, Thai \\ Nguyen province, Vietnam
}

\begin{abstract}
This study uses the Propensity Score Matching to examine the income impact of different credit sources on accessed households in the Northern Mountains of Vietnam. Results show that overall rural credit serves an important role in improving household income with respect to total income, per capita income and nonfarm income. However, different credit affects recipients heterogeneously. Whereas a significant increase in household income can be achieved through accessing commercial and informal loans, there is no significant increase of all income components associated recipients of preferential credit. These results imply that a successful credit scheme needs to consider variations in transaction costs, disbursement scheme, loan characteristics and typical socio-economic conditions of credit recipients.
\end{abstract}

\section{Keywords}

Impact, household income, rural credit, Vietnam.

Luan, D. X., Bauer, S. and Kühl, R. (2016) "Income Impacts of Credit on Accessed Households in Rural Vietnam: Do Various Credit Sources Perform Differently?", AGRIS on-line Papers in Economics and Informatics, Vol. 8, No. 1, pp. 57 - 67. ISSN 1804-1930. DOI: 10.7160/aol.2016.080106.

\section{Introduction}

The development of rural credit sector in developing countries is calling for greater evidence which implies the importance of reviewing the evidence of the credit impacts on rural households. Present literatures have showed that credit might have significant impact, no impact and mixed impacts depending on certain conditions.

A great deal of previous research has considered the provision of credit to be an effective tool for poverty reduction. For example, Guirkinger (2008) estimated the effects of formal credit and found that credit constraints lowered the total agricultural output in Peru by $26 \%$. In other words, credit improves crop productivity through the elimination of access constraints. In a similar way, Dong et al. (2012) concluded that income of farmers in the Heilongjiang province of Northeast China could be improved by $31.6 \%$ with the removal of credit constraints. One study by Mahjabeen (2008) examined the welfare impact of microcredit in Bangladesh. The author concluded that the average income and consumption of all rural households were found to increase by $73 \%$ and $50 \%$ respectively. A recent study by Milan (2012), who employed a fixed effect model with panel data to examine the social performance of microfinance institutions in Cambodia. Findings showed that that there is a remarkable increase in the mean clothing and footwear expenditures of credit recipients when compared to nonrecipients.

A number of other studies reached different conclusions, finding no positive increase in household welfare. The effects of credit were first demonstrated experimentally by Banerjee et al. (2009). In their study, 104 slums in Hyderabad of India were randomly selected to open a microcredit branch while the remaining slums were not. After 18 months of providing loans to treated areas, there was no effect of small loans on average monthly per capita expenditure, heath, education and women's decision making. The way in which credit influences productivity and efficiency of maize and tobacco in Malawi was studied extensively by Diagne and Zeller (2001). It was shown that credit has little or no impact on the technical efficiency and productivity of tobacco and maize production in Malawi. This 
finding is supported by the fact that complementary inputs such as fertilizer, land, seed, etc. are not available to farmers in the region. In an analysis of Brümmer and Loy (2000), results showed that the European Farm Credit Program from 1987 to 1994 is far more cost effective to increase competitiveness of farms over time. The finding could be interpreted as dairy farms being highly dependent on the herd scale rather than credit only. Several authors deal with the question of loan disbursement schedules. For instance, Hazarika and Alwang (2003) reported that access to credit had no significant impact on cost inefficiency among smallholder tobacco cultivators in Malawi. The credit disbursement by formal sources was faulty. Adewale and Aromolaran (2009) offer several explanatory reasons for lower efficiency of borrowers compared to non-borrowers in food crops including cassava, maize and yams of 240 households in Nigeria. Reasons could be due to the inappropriate loan disbursement schedule, small loan amount and lack of training on prudent use of loans taken. Similarly, Nghiem et al. (2007) found that credit has a small impact on household income and expenditure in Vietnam and the marginal effect has decreased over time.

Also, the evidence of the effects of credit from previous studies appears to be mixed. A recent systematic literature review by van Rooyen et al. (2012) concluded that credit has both positive and negative effects on the income of poor households in Sub-Saharan Africa. Saldias and von Cramon-Taubadel (2014) showed that different farm sectors in Chile reached disparate effects. Loan volume increased efficiency for crop farms but reduced efficiency for livestock farms. Surprisingly, credit constrained farms are less efficient in crop production, but more efficient in livestock production. Several studies confirmed the positive effects of credit but only for non-poor borrowers. For example, Coleman (2006) evaluated the impact of two microfinance programs in Northeast Thailand. He found that credit has a significantly positive impact on household welfare of committee members in terms of their wealth, savings, income, productive expenses and labor time. However, credit has an insignificant impact on the welfare of less wealthy clients. As noted by Ngo and Wahhaj (2012), credit has positive impacts under particular circumstances. Female empowerment is only enhanced when women have substantial skills to engage in an autonomous productive activity. It has conclusively been shown that production loans increase household welfare than consumption loans do.

Considering all of this evidence, it seems that the effectiveness of credit in fighting poverty depends strongly on certain situations. The aforementioned problem could hold true for Vietnam, a developing country in the Southeast Region of Asia. The poverty headcount rate in the country had reduced from nearly $58.1 \%$ of the population in 1993 to $20.7 \%$ in 2011 (Badiani et al., 2012). The provision of credit to rural households could be one of various explanations for the recent poverty reduction in Vietnam over time. However, there could be a case that not all al credit sources can benefit their recipients. This assumption is constructed on the basis that disparities in poverty reduction in Vietnam are still emerging since poverty intensity is substantially higher in disadvantaged areas. In addition, a key motivation for this study is that very little is actually known as to whether all rural credit sources in Vietnam are effective tools in fighting poverty. This study aims to fulfill this research gap in the existing literature by investigating the income impact of different credit sources on credit recipients.

\section{Materials and methods}

\section{Materials}

The Northern Upland of Vietnam representing the most disadvantaged rural area of the country is selected as a research area. It is characterized by a high proportion of rural residents $(82.14 \%)$. Its poverty rate in 2012 was $23.8 \%$, which was the highest rate among six total regions of the country (General Statistics Office of Vietnam, 2012). Although farming activities serve as the main source of livelihood for the poor in the region, these activities are characterized by a small farming scale. Rice, maize and cassava are the most common crops. A variety of pigs, cows, buffaloes, chickens, and ducks are common main species of livestock. Data of total 1338 households in 4 representative provinces in this region collected from the 2012 Vietnam Access to Resources Household Survey were used.

\section{Methods}

This study uses the Propensity Score Matching (PSM) to estimate the income impact of credit. The PSM method is one of the more practical ways of estimating impacts using cross sectional data. It also offers an effective way of examining 
the impact of credit on multiple income indicators and results are less dependent on the function forms of econometric models (Heinrich et al., 2010). The crucial approach of PSM is to hold all factors constant as much as possible so that the difference in income for credit accessed households (treated) and credit non-accessed ones (the counterfactual or control group) is due to credit. In an attempt to make impact estimation as robust as possible, this study uses all four different matching algorithms including the nearest neighbour, radius, kernel and stratification matching. Each matching algorithm to estimate one outcome variable was repeated 5000 times with bootstrapping in order to remove the sample errors. Results from all matching algorithm were averaged in order to create estimations as robust as possible.

The estimations procedure was conducted through two main steps. In the first step, the probability was estimated through a formal probit suggested by DeMaris (2004) as follows:

Probability of taking out a loan ${ }_{i}$

$$
=F\left(W_{i}\right) \int_{-\infty}^{W_{i}} \frac{1}{\sqrt{2 \pi}} \exp \left(-S^{2} / 2\right) d s
$$

For $-\infty<w_{i}<\infty ; w_{i}=Z_{i}^{\prime} \alpha$

In Model $1 ; \alpha$ is a $k$ by 1 vector of parameters to be estimated. $\mathrm{Z}$ is the $\mathrm{n}$ by $\mathrm{k}$ matrix of the explanatory variables, which are selected and explained as follows:

Age of household heads and family size are the continuous variables reflecting the heterogeneity in preferences for consumption across households. These two variables are specified as determinants of the probability that a household takes out credit.

Number of helpers is used as a proxy for household social capital. This continuous variable indicates the number of persons who are willing to provide emergent assistance if a household is in need of money. Story and Carpiano (2015) showed that a better connection with helpers facilitates household social capital, which is necessary to improve the household economic situation.

Access to agricultural extensions services is a continuous variable measured as the number of contacts with agricultural extension in the last 12 months. According to Buadi et al. (2013), access to agricultural extension services such as information support, input supply, and training helps farmers manage and use resources more effectively.
Savings volumes is a continuous variable measured in thousands VND, representing household financial capital. Savings can be converted into future production investment or food consumption in transitional seasons. Households also recognize the importance of savings in coping with shocks. Savings are therefore of an interest variable of household access to credit.

Ethnicity dummy is specified as a binary variable and specified to remove the effects of differences in socio-economic conditions between the ethnic minorities and Kinh majority in Vietnam. The initial sample consists of 1338 households, 939 of them are minorities making up $70 \%$ of households. Minorities can have more disadvantages compared to the Kinh majority in terms of household endowments.

Exposure to shocks is a binary variable defined as one if the household is hit by any types of shocks and zero otherwise. Shocks have led to a decline in household income. In agricultural production, crop and livestock shocks can reduce productivity and farm income, forcing a household to lower its level of consumption. Personal shocks such as illness, accident, and death can have a negative impact on labor productivity due to poor health conditions and therefore reduce future income. Once hit with an income shock, irrespective of the cause, a household may encounter a number of disadvantages. Taking out a loan could be a likely response of household to shocks.

In this study, four different probit models were run to account for the full sample and three different credit sources. Descriptive statistics in terms of mean, standard deviation, and maximum, minimum of both explanatory and outcome variables were computed and used for household description (see Table 1 for further details).

In the survey, households were asked to approximate the amount of net income from different sources including cash and in-kind payments. Farm income was obtained from household participation in agricultural sub-sectors including crops, livestock, aquaculture and forestry. Total nonfarm income was obtained from working outside the household for private individuals, households, governmental agencies, public work programs and enterprises. Nonfarm income was also obtained from all self-employment activities of the household such as trading, services, transportation and other self-employed business. Impacts were estimated by calculating average treatment effect on treated (ATT). The empirical estimation of the effects 


\begin{tabular}{|c|c|c|c|c|c|}
\hline Variables & Mean & Std. & N. & Min. & Max. \\
\hline \multicolumn{6}{|l|}{ Explanatory variables } \\
\hline Age of household head (years) & 47.70 & 13.793 & 1338 & 16 & 95 \\
\hline Number of helpers (persons) & 3.42 & 3.88 & 1338 & 0 & 50 \\
\hline Family size (persons) & 4.94 & 2.06 & 1338 & 1 & 15 \\
\hline Ethnicity $(1=$ minorities $)$ & .70 & .46 & 1338 & 0 & 1 \\
\hline Exposure to shocks (1=yes) & .71 & .45 & 1338 & 0 & 1 \\
\hline $\begin{array}{l}\text { Number of contacts with agricultural } \\
\text { extension (number) }\end{array}$ & 1.38 & 2.22 & 1338 & 0 & 20 \\
\hline Savings volume (1000VND) & 9587.40 & 34869.86 & 1338 & 34869.86 & 605000 \\
\hline \multicolumn{6}{|l|}{ Outcome variables } \\
\hline Total income (1000VND) & 50950.44 & 49858.38 & 1338 & 2390 & 535650 \\
\hline Farm income (1000VND) & 29476.04 & 28028.24 & 1338 & 3960 & 380182 \\
\hline Non-farm income (1000VND) & 21474.4 & 42135.37 & 1338 & 0 & 530250 \\
\hline
\end{tabular}

Source: own processing

Table 1: Descriptive statistics of selected explanatory variables and outcome variables.

of credit on household income is expressed as follows:

$$
A T T=\frac{1}{n_{1}} \sum\left[Y_{1}-\sum w(i, j) Y_{0}\right]
$$

ATT denotes the average effects of credit on accessed household; $n_{1}$ is the number of accessed households; $Y_{1}$ is the average income of accessed households; $Y_{0}$ is the average income of the matched non-accessed households; and $w(i, j)$ are weights.

\section{Results and discussion}

\section{Loan characteristics}

In rural Vietnam, the supply of rural credit is currently served by two main sectors including the formal and informal part. The formal sector covers the two state-owned banks including the Vietnam Bank for Agriculture and Rural Development (Agribank) and the Vietnam Bank for Social Policy (VBSP). The Agribank was established in 1998 under the reform of the financial system and the introduction of commercial banks in Vietnam. It mainly provides loans and other financial services to agricultural and rural sectors. Since the end of 2001, it has become the leading commercial bank with the most extensive network of branches in rural areas. The establishment of the VBSP represents the governmental intervention on rural credit markets in Vietnam. The subsidised bank, established in 2002, has the mission of providing preferential credits to the poor and low income households. The lending procedure is conducted through entrusted local organizations such as women's unions and farmer's unions. Those organizations are the main channels through which preferential loans are delivered, with subsidised interest rates. The subsidised VBSP relies on guarantors as local authorities to grant loans without physical collateral security such as land titles. Borrowers should be in the list of poor households of local communes. Borrowers are exempted from borrowing fee but must be a member of savings and credit group, selected by the group and named in the list proposed to get loan with certification of local people's committee. The last sector, the informal sector, incorporates private moneylenders, private traders, relatives and friends. In this study, accessed households are divided into three sub-groups including access to the preferential, commercial and informal credit. Table 2 provides the summary of statistics for various characteristics of credit.

As shown in Table 2, credit characteristics are quite different between credit sources. The average credit volume is substantially lower in formally preferential credit compared to commercial and informal loans. The average credit amount from moneylenders is higher than that obtained from private traders, relatives and friends. Credit from the Agribank is normally required by collateral security such as land use certificate, whereas credit from private traders relies on mutual trust created through long and close relationships between themselves and borrowers. Private traders are tied to activities such as the sale of output so as to overcome the problem of incomplete information. The preferential credit from the VBSP bank relies on guarantors as local authorizes to grant loans 


\begin{tabular}{|c|c|c|c|c|c|c|c|}
\hline \multirow[t]{2}{*}{ Sources of loan } & \multicolumn{2}{|c|}{$\begin{array}{l}\text { Loan amount } \\
\text { (1000VND) }\end{array}$} & \multicolumn{2}{|c|}{$\begin{array}{l}\text { Loan duration } \\
\text { (months) }\end{array}$} & \multicolumn{2}{|c|}{$\begin{array}{c}\text { Monthly } \\
\text { interest rate }(\%)\end{array}$} & \multirow{2}{*}{$\begin{array}{c}\text { Collateral } \\
\text { requirement } \\
(\% \text { of households } \\
\text { Mean }\end{array}$} \\
\hline & Mean & Std. & Mean & Std. & Mean & Std. & \\
\hline $\begin{array}{l}\text { Preferential credit } \\
\text { of the VBSP }(n=259)\end{array}$ & 18947.49 & 17531.34 & 47.83 & 22.54 & 0.62 & 0.2 & 6.69 \\
\hline $\begin{array}{l}\text { Formal commercial credit } \\
\text { of the Agribank }(n=71)\end{array}$ & 57947.89 & 130864.5 & 29.03 & 15.87 & 1.36 & 0.5 & 87.84 \\
\hline Informal credit $(n=104)$ & 27383.65 & 36461.55 & 14.86 & 9.84 & 0.94 & 0.97 & 4.93 \\
\hline Private trader $(n=15)$ & 11697.73 & 15050.92 & 4.75 & 1.48 & 3.62 & 1.76 & 0 \\
\hline Private money lender $(n=9)$ & 31888.88 & 53370.82 & 7 & 7.07 & 2.32 & 1.31 & 22.22 \\
\hline Relatives, friends $(n=80)$ & 29817.92 & 38573.75 & 17.65 & 11.72 & 0.28 & 0.78 & 0 \\
\hline
\end{tabular}

Table 2: Loan characteristics by lenders.

without physical collateral security. Free collateral loans from the VBSP are in line with the poverty targeting of the bank.

Preferential credit has the longest duration compared to the remaining credit sources. A possible explanation for this is that providing the poor with a longer duration of preferential credit enhances their ability to repay. In contrast, it seems possible that borrowers of moneylenders or private traders prefer the shorter-term financing to reduce the cost of interest rates.

The subsidised VBSP charged much lower interest rates because the bank receives subsidies from the government to provide preferential credit to the poor. Interest rates charged by moneylenders and private traders are notably higher than those by banks and other informal sources. Due to such high interest rates, borrowers may resort to moneylenders and private traders only for temporary shortages of capital or for immediate consumption needs. The interest rate charged by informal sources on average was around $0.94 \%$, which is higher than that of preferential credit provided by the Vietnam Bank for Social Policies, but still lower than the average interest rate of the Agribank. The reason for this is that informal loans from friends and relatives account for $76.92 \%$ of the total informal loans. People tend to charge low or zero interest rates for their friends and relatives.

Table 3 describes credit use structure across credit accessed household groups. Mainly, credit was used for livestock production, house purchase or building, and payment of educational fees. Still, a small proportion of recipients used credit for unproductive purposes such as purchasing family food or paying for school fees and medical fees.
It is possible that allocating credit for such purposes leads to positive impacts on the education of children and health of family members. However, the longterm effects tend to be in excess of estimation in this current work. Also, credit was used differently depending on their source. For instance, while the majority of preferential credit was used to finance farming activities, formal commercial credit was also used for nonfarm investment. The difference can be explained in part by the higher profitability when investing in nonfarm activities such as small trading. Short-term needs such as health expenses are normally financed by informal sources such as moneylenders, relatives and friends.

2. Household characteristics influencing access to different credit sources

Table 4 presents the estimated four probit models describing participation in the overall credit, commercial, preferential and informal credit program respectively. In each model, the dependent variable is a binary variable with a value of 1 if a household took out credit and zero otherwise. Table 4 only reports relevant variables, which significantly influence participation in the credit intervention. This helps to avoid exacerbating the common support problem of unnecessary variances of the impact estimates in the second stage of the Propensity Score Matching (Heinrich et al., 2010). The table shows that statistics such as LR Chi squared, p-value yield encouraging results. The rates of correct classification in four models are estimated to be $67.41 \%, 94.69 \%, 80.64 \%$ and $92.23 \%$ respectively.

Results show that number of helpers, frequency of accessing agricultural extension services, age of household heads, amount of savings, and exposure to shocks were found to significantly influence 


\begin{tabular}{|c|c|c|c|c|c|}
\hline \multirow[t]{2}{*}{ Loan use purposes } & \multicolumn{2}{|c|}{ Formal credit } & \multicolumn{3}{|c|}{ Informal credit } \\
\hline & $\begin{array}{l}\text { Preferential } \\
\quad(n=259)\end{array}$ & $\begin{array}{l}\text { Commercial } \\
(\mathrm{n}=71)\end{array}$ & $\begin{array}{l}\text { Private trader } \\
\quad(n=15)\end{array}$ & $\begin{array}{l}\text { Private money } \\
\qquad(n=9)\end{array}$ & $\begin{array}{l}\text { Relatives, friends } \\
\qquad(\mathrm{n}=80)\end{array}$ \\
\hline Rice & 2.46 & 2.7 & 0 & 0 & 1.98 \\
\hline Other crop & 1.06 & 2.7 & 0 & 0 & 2.97 \\
\hline Livestock & 33.1 & 18.92 & 12.5 & 0 & 15.84 \\
\hline Nonfarm activity & 2.11 & 14.86 & 0 & 22.22 & 9.9 \\
\hline Repay other loans & 0.35 & 2.7 & 0 & 0 & 0 \\
\hline Build/buy house & 11.97 & 18.92 & 12.5 & 22.22 & 12.87 \\
\hline Buy land & 2.46 & 0 & 0 & 0 & 0 \\
\hline Buy another asset & 4.23 & 1.35 & 0 & 0 & 7.92 \\
\hline Pay for wedding/funeral & 1.06 & 1.35 & 12.5 & 0 & 3.96 \\
\hline Education expenses & 12.68 & 6.76 & 0 & 11.11 & 5.94 \\
\hline Health expenses & 1.76 & 1.35 & 12.5 & 11.11 & 7.92 \\
\hline General consumption & 4.93 & 8.11 & 25 & 11.11 & 10.89 \\
\hline Other & 21.83 & 20.27 & 25 & 22.22 & 19.8 \\
\hline Total & 100 & 100 & 100 & 100 & 100 \\
\hline
\end{tabular}

Source: own processing

Table 3: Credit use purposes by sources of loans ( $\%$ of households).

\begin{tabular}{|c|c|c|c|c|c|c|c|c|}
\hline \multirow{2}{*}{ Predictors } & \multicolumn{2}{|c|}{ Full sample } & \multicolumn{2}{|c|}{ Commercial credit } & \multicolumn{2}{|c|}{ Preferential credit } & \multicolumn{2}{|c|}{ Informal credit } \\
\hline & Coefficient & z-value & Coefficient & z-value & Coefficient & z-value & Coefficient & z-value \\
\hline Intercept & 1.006 & $2.06^{* *}$ & -1.281 & $-11.46^{* * *}$ & -0.1226 & -0.21 & -0.0236 & -0.03 \\
\hline Log (Number of helpers) & 0.2007 & $4.14 * * *$ & 0.3244127 & $3.79 * * *$ & 0.1881 & $3.40 * * *$ & 0.135 & $1.97 * *$ \\
\hline Ethnicity ( $1=$ ethnic minorities) & - & & -0.5608 & $-4.71 * * *$ & 0.3109 & $2.78 * * *$ & -0.5022 & $-4.38 * * *$ \\
\hline $\begin{array}{l}\log \text { (Number of contacts } \\
\text { with agricultural extension) }\end{array}$ & 0.1506 & $2.42 * *$ & - & & - & & - & \\
\hline Log(Age of household heads) & -0.4307 & $-3.43 * * *$ & - & & -0.4427 & $-3.04 * * *$ & -0.3882 & $-2.12^{* *}$ \\
\hline Log( Savings volumes) & -0.0521 & $-5.82 * * *$ & -0.033 & $-2.42 * *$ & -0.0404 & $-3.90 * * *$ & - & \\
\hline Exposure to shocks $(1=$ yes $)$ & 0.2925 & $3.52 * * *$ & - & & 0.2492 & $2.50 * *$ & 0.3628 & $2.88^{* * *}$ \\
\hline Log(Family size $)$ & - & & - & & 0.3517 & $3.29 * * *$ & - & \\
\hline Number of observations & 1338 & & 1338 & & 1338 & & 1338 & \\
\hline Prob $>$ chi 2 & 0 & & 0 & & 0 & & 0 & \\
\hline LR chi2(3) & - & & 42.53 & & - & & - & \\
\hline LR chi2(4) & & & & & & & 31.87 & \\
\hline LR chi2(5) & 72.64 & & - & & - & & - & \\
\hline LR chi2(6) & - & & - & & 79.88 & & - & \\
\hline Pseudo R2 & 0.0429 & & 0.0766 & & 0.0608 & & 0.0436 & \\
\hline Correctly classified (\%) & $67.41 \%$ & & $94.69 \%$ & & $80.64 \%$ & & $92.23 \%$ & \\
\hline
\end{tabular}

Note: $* * *$ significant at $1 \%, * *$ significant at $5 \%, *$ significant at $10 \%$

Source: own processing

Table 4: Probit estimation of household characteristics influencing access to credit.

access to overall rural credit. In addition, these factors affected credit access differently depending on each credit source. The most intriguing results to emerge from the analysis of credit access are as follows: Age of household heads and the number of people who could extend emergency help explain the probability at which credit has been accessed. Younger household heads are more likely to receive credit. Perhaps those households demonstrate active participation in local mass organizations such as women's unions or farmers' unions. The younger heads could be more active in obtaining information regarding credit sources, farming technologies and business opportunities. Family size is perceived to be associated with accessing preferential credit. This could be explained 
by the fact that larger households tend to be poorer ethnic minorities who receive a focus of preferential credit programs. Exposure to shocks may very well increase demand for loans, because households seek credit in order to smooth consumption when they have been hit by a negative income shock. The ethnic minority community was observed to be more likely to access preferential credit but less likely to receive commercial and informal credit. Analysis further revealed that households receiving extension services are more likely to take out loans. In addition, households which are able to accumulate a larger amount of savings are less likely to access credit in general.

3. Income impact of different credit sources on accessed households

This study focuses on total household income and its components to examine impacts of credit. Regarding household income, there are household observations (outliers), which are distant from the other observations. Those outliers can distort impact estimators and yield unreliable results. For this reason, visualization through a box-plot is used to detect outliers. It is therefore a total of 114 household observations of outlays that are removed to smooth data for better comparisons. When examining the income impacts of a particular source of credit, households with access to other financial sources are excluded. For instance, in order to separate the impact of subsidized credit, 56 recipients of Agribank credit, and 91 recipients of informal credit are removed from analyses. Similarly, this procedure is conducted in estimating income effects of other credit sources. Table 5 provides results obtained from the Propensity Score Matching.

For full sample, the credit recipients had increased for total income of $13.96 \%$, for per capita income of $15.65 \%$, and nonfarm income of $32.50 \%$. All those coefficients are statistically significant at a $5 \%$ level of statistical significance. Although credit has a positive impact on farm income, the coefficient is very small and statistically insignificant.

The other finding is that different credit sources perform differently. The evidence shows that the income impact of commercial credit lies in the level of $23.64 \%$ of total income, $33.65 \%$ of per capita income, and $65.22 \%$ of total nonfarm income. Commercial credit decreases total farm income of accessed households by $27.85 \%$. This could be explained by the fact that commercial loans were mainly used for financing nonfarm activities such as trading, services, transportation and other self-employed business. This main credit use purpose can be due to the higher returns when investing in nonfarm activities which suffer fewer natural and biological risks (floods, droughts, crop and animal diseases). Rates of income impact of informal credit are $18.82 \%$ of total income and $14.85 \%$ of per capita income. All those coefficients are statistically significant at a $5 \%$ level of statistical significance. In contrast,

\begin{tabular}{|c|c|c|c|c|c|}
\hline \multirow{2}{*}{ Household income } & \multirow{2}{*}{ Indicators } & \multirow{2}{*}{ Full sample } & \multicolumn{2}{|c|}{ Formal credit } & \multirow{2}{*}{ Informal credit } \\
\hline & & & Preferential & Commercial & \\
\hline \multirow{3}{*}{ Total income } & $1000 \mathrm{VND}$ & $5071.41 * * *$ & 1939.59 & $8653.86^{* *}$ & $7323.41 * *$ \\
\hline & $\%$ change & $13.96 \%$ & $5.41 \%$ & $23.64 \%$ & $18.82 \%$ \\
\hline & t-statistics & 3.20 & 1.00 & 2.47 & 2.28 \\
\hline \multirow{3}{*}{ Per capita income } & $1000 \mathrm{VND}$ & $1300.50 * *$ & 216.27 & $3516.87 * *$ & 1414.08 \\
\hline & $\%$ change & $15.65 \%$ & $3.01 \%$ & $33.65 \%$ & $14.85 \%$ \\
\hline & t-statistics & 2.51 & 0.45 & 2.16 & 1.61 \\
\hline \multirow{3}{*}{ Total farm income } & $1000 \mathrm{VND}$ & 23.34 & 343.39 & $-4211.70 * *$ & 1283.32 \\
\hline & $\%$ change & $0.19 \%$ & $1.66 \%$ & $-27.85 \%$ & $7.39 \%$ \\
\hline & t-statistics & 0.15 & 0.25 & -2.10 & 0.74 \\
\hline \multirow{3}{*}{ Total non-farm income } & $1000 \mathrm{VND}$ & $3655.58 * *$ & 1117.32 & $9300.27 * *$ & 4150.89 \\
\hline & $\%$ change & $32.50 \%$ & $12.17 \%$ & $65.22 \%$ & $32.92 \%$ \\
\hline & t-statistics & 2.43 & 0.63 & 2.51 & 1.33 \\
\hline Number of treatment & & 362 & 229 & 54 & 79 \\
\hline Number of control & & 647 & 567 & 615 & 584 \\
\hline
\end{tabular}

Note: $*$ Significant at $10 \% ; * *$ significant at $5 \% ; * * *$ significant at $1 \%$ Source: own processing

Table 5: Average income impact of credit on accessed households. 
there are positive but not statistically significant increases of all total income components associated with recipients of preferential credit.

All mentioned coefficients measure the absolute magnitude of impact, which refer to the difference in mean of income between credit recipients and non-recipients with similar characteristics. However, it is also relevant to examine the relative impact per unit of loan amount. The total income impact per unit of loan is calculated by taking the income difference divided by the corresponding amount of credit (Figure 1).

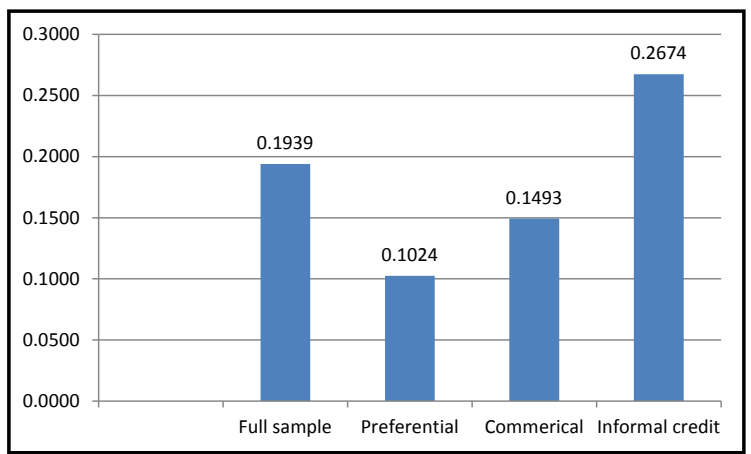

Source: own processing

Figure 1: Total income impact per VND million of credit amount.

As Figure 1 shows, considering all four different matching algorithms, one million VND of credit volume increased household income by 0.1939 million VND. Similarly, the impact of one unit of credit volume on household income was also calculated for different credit sources. A comparison of the impact per unit of loan volume reveals that informal credit tends to have the greatest impact on household income, followed by commercial credit and preferential credit. The governmental financial intervention via preferential credit is necessary to reach the poor but does not significantly change household income.

It is helpful to further explain how informal and commercial credits are supplying more proficiently than preferential credit. Provision of commercial credit has substantially enhanced total household incomes, especially nonfarm income. These results could be explained by the fact that the Agribank better fulfills the credit demand of households on the basis of market principles. The bank is a profit-oriented organization, which may be somewhat limited by serving the wealthier rather than the poor. In addition, accessed households of the Agribank appear to use credit for financing nonfarm activities, which suffer fewer risks compared to farming activities. The positive effects this credit source can explain the increasing share of commercial credit in rural credit market during the last two decades.

Regarding the preferential credit, a number of other previous studies evaluating its effects observed consistent results with those in this study. For instance, Dufhues and Buchenrieder (2005) indicated that the provision of preferential credit represents an attempt by the government to broaden access in general. However, this increase in outreach is in conjunction with an increase in access to credit for non-creditworthy households, resulting in decreased repayment rates or limited welfare impact. Findings in this study complement those of Banerjee et al. (2009), who argued that by charging a reduced rate below the inflation level, the preferential credit program discourages savings and encourages low return investments - the purchase of durables for consumption purposes for instance. As a consequence, preferential credit does not contribute to increasing household income, at least in the short term. A recent study by Saint-Macary and Zeller (2012) involved the efficiency of rural credit policy in Yen Chau, a mountainous district in Northern Upland of Vietnam. Accordingly, preferential credit has been found to be inefficient in reducing poverty and improving agricultural growth. In another major study, Barslund and Tarp (2008) reported that a "one size fits all" method to scaling up preferential credit is not going to be the most advantageous. The expansion of preferential credit requires careful consideration for the need for credit in areas where access is presently low. The inefficiency may have been caused by the supply-driven credit program, (as opposed to demand-driven) which led to credit rationing and misallocation. The subsidized bank naturally performs as a government organization carrying out credit distribution policies, which are highly dependent on administrative and political uncertainties. Under such conditions, preferential credit does not react to the high demand for frequent credits to fund consumption and purchase agricultural input.

The finding in this study confirms the role of informal credit in improving total household income. The findings of the current study support the previous research on the role of informal credit. For instance, Cuong and Van den Berg (2011) concluded that informal credit in Vietnam was rather worthwhile, as it narrowed the poverty rate of recipients by $8 \%$. Informal credit remains an essential source of credit for the poor in Vietnam. This view is also supported by Khoi 
et al. (2013) who argues that formal and informal coexist in rural areas of Vietnam. Similarly, Lainez (2014) suggests that informal credit is a necessity rather than an evil in the country. It may be that participants in informal credit markets benefitted from good access to information between lenders and borrowers originated from social relationships within social relationships. Due to a magnificent level of trust, the informal sector can supply adaptable loan contract terms regarding maturity, interest rates and repayment mode. In the same vein, a study by Barslund and Tarp (2008) conducted in four provinces of Vietnam notes that informal credit includes private money lenders, friends and relatives, representing about one third of all loans. Poor rural households persist with informal networks and relatives. In this study, the larger portion of loans is from relatives and friends in total informal loans. These results support the argument of Cuong (2006) which indicated that money lenders were crowded out by the formal credit sector because of competition.

\section{Conclusion}

Provision of credit to rural households has increased their total income, per capita income and nonfarm income. It is apparent from this study that overall rural credit has contributed to the remarkable achievement in poverty reduction of Vietnam in the last two decades. However, various types of credit affected recipients differently. Strong evidence of positive impact was found when households received commercial credit from the Agribank. In addition, informal credit is still an important component in the credit system and plays a role in improving household income. However, the impact of preferential credit was not very encouraging. A clear benefit for households in the intervention of preferential credit could not be identified in this analysis.

Corresponding author:

Do Xuan Luan

Faculty of Economics and Rural Development, Thai Nguyen University of Agriculture and Forestry Thai Nguyen province, Vietnam

Phone: 84 987807896,Email: doxuanluan@gmail.com

\section{References}

[1] Adewale, T. and Aromolaran, A. (2009) "Micro-credit and Technical Efficiency in Food Crops Production: A Stochastic Frontier Approach: Adv", Advances in Natural and Applied Sciences, Vol. 3, pp. 156-165. ISSN 1995-0772.
Provision of commercial credit has enhanced household incomes, and there is therefore a definite need for the expansion of this credit source. Continued efforts are needed to make those loans more accessible to the poorer households. However, the challenge is how to improve the willingness of a profit-driven bank to increase credit size as well as spread out credit to the poorer households. The other implication from this study is that the limited role of preferential credit in improving household incomes might not be attributed to preferential credit itself. Preferential credit is very important to reach the poor who are constrained to access commercial credit from the banking system. However, in order to improve effectiveness, preferential credit schemes should be improved in terms of a reduction in administrative procedures, timely credit delivery to make credit more appropriate to the seasonality of farming activities, and the cash flow of income and expenditure of the poor. Those serve as a base for improving the creditworthiness of the poor. At the same time, by improving quality of credit attributes, the subsidized bank might be able to attain financial sustainability and target the poor concurrently. The final implication from this study is that informal credit plays a role in helping households fulfill capital demand for production and smooth consumption fluctuations. Informal credit responds to the capital needs of households in a timely manner.

\section{Acknowledgements}

We would like to thank Central Institute for Economic Management (CIEM) of Vietnam for providing this valuable data. Appreciation also to the editor and two anonymous reviewers for their excellent comments that helped us to improve the article. 
[2] Badiani, R., Baulch, B., Brandt, L., Dat, V., Giang, N., Gibson, J. and Wells-Dang, A. (2012) Vietnam poverty assessment-Well Begun, Not Yet Done: Vietnam's Remarkable Progress on Poverty Reduction and the Emerging Challenges. [Online] Available: http://documents. worldbank.org/curated/en/2013/08/18124050/2012-vietnam-poverty-assessment-well-begunnot-yet-done-vietnams-remarkable-progress-poverty-reduction-emerging-challenges [Accessed: 6 November 2015].

[3] Banerjee, A. V., Duflo, E., Glennerster, R. and Kinnan, C. (2009) The miracle of microfinance? Evidence from a randomized evaluation. Working Paper. MIT.

[4] Barslund, M. and Tarp, F. (2008) "Formal and informal rural credit in four provinces of Vietnam", The Journal of Development Studies, Vol. 44, pp. 485-503. ISSN 0022-0388.

[5] Brümmer, B. and Loy, J. P. (2000) "The technical efficiency impact of farm credit programmes: A case study of northern Germany”, Journal of Agricultural Economics, Vol. 51, pp. 405-418. ISSN 1477-9552.

[6] Buadi, D. K., Anaman, K. A. and Kwarteng, J. A. (2013) "Farmers' perceptions of the quality of extension services provided by non-governmental organisations in two municipalities in the Central Region of Ghana", Agricultural Systems, Vol. 120, pp. 20-26. ISSN 0308-521X, doi: http://dx.doi.org/10.1016/j.agsy.2013.05.002.

[7] Coleman, B. E. (2006) "Microfinance in Northeast Thailand: Who benefits and how much?", World Development, Vol. 34, pp. 1612-1638. ISSN 0305-750X. doi: http://dx.doi.org/10.1016/j. worlddev.2006.01.006.

[8] Cuong, N. V. (2006) Determinants of credit participation and its impact on household consumption: Evidence from rural Vietnam. Paper presented at the Paper presented at the $3^{\text {rd }}$ Leicester Ph.D. Conference on Economics.

[9] Cuong, N. V., and Van den Berg, M. (2011) The impact of Informal Credit on Poverty and Inequality: The Case of Vietnam, University Library of Munich, Germany.

[10] DeMaris, A. (2004) Regression with social data: Modeling continuous and limited response variables (Vol. 417), John Wiley \& Sons. p. 560. ISBN: 0471677558.

[11] Diagne, A. and Zeller, M. (2001) Access to credit and its impact on welfare in Malawi (Vol. 116), Intl Food Policy Res Inst, p. 153. ISBN: 0896291197.

[12] Dong, F., Lu, J. and Featherstone, A. (2012) "Effects of Credit Constraints on Household Productivity in Rural China", Agricultural Finance Review, Vol. 72, pp. 402-415. ISSN 0002-1466.

[13] Dufhues, T., \& Buchenrieder, G. (2005) Outreach of credit institutes and households' access constraints to formal credit in Northern Vietnam. Discussion Paper (No. 01/2005), Institute of Agricultural Economics and Social Sciences in the Tropics and Subtropics, Universtity of Hohenheim.

[14] General Statistics Office of Vietnam, G. S. O. (2012) Statistical Handbook of Vietnam. Ha Noi: Statistical Publishing House.

[15] Guirkinger, C. (2008) "Understanding the Coexistence of Formal and Informal Credit Markets in Piura, Peru”, World Development, Vol. 36, pp. 1436-1452. ISSN 0305-750X, doi: http://dx.doi. org/10.1016/j.worlddev.2007.07.002.

[16] Hazarika, G. and Alwang, J. (2003) "Access to credit, plot size and cost inefficiency among smallholder tobacco cultivators in Malawi”, Agricultural Economics, Vol. 29, pp. 99-109. ISSN 0169-5150, doi: http://dx.doi.org/10.1016/S0169-5150(03)00020-3.

[17] Heinrich, C., Maffioli, A. and Vazquez, G. (2010) A primer for applying propensity-score matching. [Online] Available: http://www.iadb.org/document.cfm?id=35320229\%26pubDetail=1\%26wt docType $=$ Technical\%20Notes\%26wt_docnum $=35320229 \% 26 \mathrm{wt}$ language $=$ en $\% 26 \mathrm{wt}$ department $=\mathrm{SPD} / \mathrm{SDV}$ [Accessed: 6 November 2015]. 
[18] Khoi, P. D., Gan, C., Nartea, G. V. and Cohen, D. A. (2013) "Formal and informal rural credit in the Mekong River Delta of Vietnam: Interaction and accessibility", Journal of Asian Economics, Vol. 26, pp. 1-13. ISSN: 1049-0078.

[19] Lainez, N. (2014) "Informal Credit in Vietnam: A Necessity Rather Than an Evil”, Journal of Southeast Asian Economies (JSEAE), Vol. 31, pp. 147-154. ISSN 2339-5206.

[20] Mahjabeen, R. (2008) "Microfinancing in Bangladesh: Impact on households, consumption and welfare", Journal of Policy Modeling, Vol. 30, pp. 1083-1092. ISSN 0161-8938, doi: http://dx.doi.org/10.1016/j.jpolmod.2007.12.007.

[21] Milan, F. M. (2012). Social performance of microfinance institutions: theory and empirical evidence (Dissertation). [Online] Available: http://opus.uni-hohenheim.de/volltexte/2012/774/ [Accessed: 7 July 2015].

[22] Nghiem, H. S., Coelli, T. J. and Rao, P. (2007). The welfare effects of microfinance in Vietnam: empirical results from a quasi-experiment survey. Paper presented at the $51^{\text {st }}$ Annual Conference of the Australian Agriculture and Resources Economics Society.

[23] Ngo, T. M.-P. and Wahhaj, Z. (2012) "Microfinance and gender empowerment", Journal of Development Economics, Vol. 99, pp. 1-12. ISSN 0304-3878, doi: http://dx.doi.org/10.1016/j. jdeveco.2011.09.003.

[24] Saint-Macary, C. and Zeller, M. (2012). Rural credit policy in the mountains of Northern Vietnam: sustainability, outreach and impact. Paper presented at the Uplands Conference 2012 'Sustainable Land Use and Rural Development in Mountain Areas', Stuttgart, Germany.

[25] Saldias, R. and von Cramon-Taubadel, S. (2014) "Access to credit and the determinants of technical inefficiency among specialized small farmers in Chile", Chilean Journal of Agricultural Research. ISSN 0718-5839, doi: http://dx.doi.org/10.4067/S0718-58392014000400006.

[26] Story, W. T. and Carpiano, R. (2015) "Household social capital and socioeconomic inequalities in child undernutrition in rural India: Exploring institutional and organizational ties", Annals of Global Health, Vol. 81, pp. 119-120. ISSN 2214-9996, doi: http://dx.doi.org/10.1016/j. aogh.2015.02.775.

[27] van Rooyen, C., Stewart, R. and de Wet, T. (2012) "The Impact of Microfinance in Sub-Saharan Africa: A Systematic Review of the Evidence”, World Development, Vol. 40, pp. 2249-2262. ISSN 0305-750X, doi: http://dx.doi.org/10.1016/j.worlddev.2012.03.012. 